GROUP EDITORIAL FOR SPECIAL ISSUE ON COOPERATIVES AND

ALTERNATIVE FOOD SYSTEMS INITIATIVES

\title{
Working together to build cooperative food systems
}

Colin Ray Anderson, Centre for Agroecology, Water and Resilience, Coventry University, UK

Lynda Brushett, Cooperative Development Institute, USA

Thomas W. Gray, U.S. Department of Agriculture, Rural Development-Cooperative Programs, USA, and Center for the Study of Cooperatives, University of Saskatchewan, Canada

Henk Renting, RUAF Foundation (International Network of Resource Centres on Urban Agriculture and Food Security), the Netherlands

Submitted May 30, 2014 / Published online June 24, 2014

Citation: Anderson, C. R., Brushett, L., Gray, T. W., \& Renting, H. (2014). Working together to build cooperative food systems [Editorial]. Journal of Agriculture, Food Systems, and Community Development, 4(3), 3-9. http://dx.doi.org/10.5304/jafscd.2014.043.017

Copyright (C 2014 by New Leaf Associates, Inc.

$\mathrm{T}$ he combined challenges of food insecurity, agriculture-related environmental decline, corporate concentration, and the decline of community resilience are being met by growing societal interest in developing more just and sustainable food systems. A recent emphasis on cooperation and innovative forms of collective action within the food movement invokes a

Colin Ray Anderson, Centre for Agroecology, Water and Resilience, Coventry University, UK;

colinrayanderson@gmail.com

Lynda Brushett, Cooperative Development Institute, USA; lyndabrushett@gmail.com

Thomas W. Gray, U.S. Department of Agriculture, Rural Development-Cooperative Programs, and Center for the Study of Cooperatives, University of Saskatchewan; Thomas.Gray@wdc.usda.gov

Henk Renting, RUAF Foundation, the Netherlands; rentingh@gmail.com community-centered approach to food provisioning where collective problem-solving and democracy take center place in the development agenda (Ikerd, 2012). Cooperative alternative food networks are becoming powerful tools for community development and important vehicles for cultivating democratically controlled food systems at multiple scales. The papers in this special issue provide an important contribution to our understanding of the function, the challenges, and the potential of collective action in enabling more just and resilient food systems.

Cooperative alternative food networks represent a break from the competitive productivism ${ }^{1}$ of

\footnotetext{
${ }^{1}$ Productivism is the belief that the main purpose of agriculture is to maximize the production of food and fiber. The productivist agriculture paradigm has been criticized for externalizing considerations of environment, community, and social justice.
} 
the dominant food economy and create new relational spaces that hold promise for overcoming the pragmatic and political limits of some of the more individualistic approaches in the local/ sustainable food movement. These include cooperative forms of: food hubs, local food networks, farmers' markets, CSAs, box schemes, buying clubs, and value chains, along with a range of agriculture and food cooperatives owned by farmers, consumers, workers, and in emerging multistakeholder cooperative structures. With a renewed emphasis on civic governance, the resulting food-provisioning systems are based on principles of participatory democracy, solidarity, and reciprocity (Renting, Schermer, \& Rossi, 2012) and provide spaces to nurture collective subjectivities required for transformative food practice and politics (Levkoe, 2011).

Organized formally through cooperative legal structures or through cooperative governance approaches in informal groups, associative economic networks, nonprofit organizations, or other entities, cooperative alternative food networks provide an alternative to the dominant or conventional food system by (a) reconnecting farmers and consumers in more direct and meaningful ways; (b) selling direct to local, regional, and global (fairtrade) markets; (c) creating alternative market channels such as CSAs, farm-to-school programs, buying clubs, and farmers' markets; and (d) promoting food production, distribution, and consumption processes that are environmentally sound and produce healthier food.

Cooperation is at the heart of a transition beyond the more individualistic and inward focused "first generation" localization efforts in the food movement to second-generation ones that involve practical and political mobilization at larger scales of organization (Goodman, Goodman, \& DuPuis, 2011). These can be contrasted with the large-scale, profit-oriented marketing cooperatives that have developed in some countries (most notably in Europe), which have lost much of their dynamism and emancipatory potential. Rather, cooperative alternative food networks involve emergent forms of collective action that are reoriented toward democratic principles and are more explicitly located within a social movement agenda. As a whole, cooperative alternative food networks combine the principles of the cooperative institution (Gray, 2008) with the politics of the food movement (Levkoe \& Wakefield, 2014) through experiments in democratic socio-economic interdependence in a vision of a more resilient and just food system.

The nine peer-reviewed papers plus one commentary in this special issue of JAFSCD explore the state of the art in cooperative alternative food networks and exemplify the diversity and dynamism of the field. Three of the papers discuss the role of cooperative support organizations in enabling the development of cooperative regional food systems. Greg Cameron and Louise

Hanavan chart the state of regional cooperative development and the policy context of agriculture cooperatives in the Canadian Maritimes. Their analysis suggests that state support for cooperative development is being eroded as provincial and federal governments increasingly turn toward neoliberal modes of governance. In this context, grassroots innovations such as cooperative alternative food networks tend to be poorly supported by governments that narrowly couch economic progress in terms of large-scale development projects and commodity agriculture (Anderson \& McLachlan, 2012).

This policy context creates a challenging climate for cooperatives pursuing a more holistic community development model and those promoting multifunctional agriculture. In this gap, Cameron suggests that agriculture cooperatives would be better positioned with a coordinated approach to developing a regional cooperative economy through a tertiary organizational structure. This paper also raises important questions about the role of conventional agricultural cooperatives in this transition and whether this turn toward a more regionally focused food system is viewed as compatible with, or as a viable alternative for, these larger cooperatives. Indeed it may be possible that the organizational structures and norms of larger cooperatives are incompatible with the values and flexibility required by these participatory and civic socio-economic forms, which may be better developed from the bottom up (Cleveland, Müller, Tranovich, Mazaroli, \& Hinson, 2014). 
Cameron's emphasis on regional coordination among cooperatives is also illustrated in the paper offered by Jennifer Sumner, J.J. McMurtry, and Hannah Renglich. This Canadian case study of the Ontario Local Organic Food Network exemplifies how the cooperative advantage can be leveraged through support structures that intentionally create linkages and synergies between cooperatives in the fast-growing local, organic agrifood sector. Here, the principle of cooperation among cooperatives becomes embodied institutionally through a cooperative support network. The paper provides a promising model and analytical framework that can inform the development of more integrated regional food systems in other geographic localities. The further development of cooperative networks and federations at regional, national, and international scales will provide important opportunities to enable social learning, the diffusion of innovation between cooperatives, and the development of cooperative business relationships within and between sectors of the cooperative alternative food system.

Kathi Beratan, Pamela Jackson, and Sherrie Godette provide insight into cooperative development challenges among small, socially disadvantaged producers through a case study of four farmer groups in North Carolina. Their cautionary narrative shows how a one-size-fits-all development approach can undermine the potential of cooperatives for rural development. The paper underscores how the economistic and asset-based approaches often taken by cooperative developers are too narrow in focus and are unlikely to provide appropriate support without careful consideration of the modes by which social and cultural factors mediate capacity-building and cooperation among diverse cooperators.

These social and cultural dynamics are examined in the case study presented by Colin

\section{Anderson, Wayne McDonald, Jo-Lene} Gardiner, and Stephane McLachlan, who chronicle the development of a farmer-driven civic food network in the Canadian Prairies. The case study suggests that democratic and open cooperative alternative food networks will inevitably draw together participants with diverging priorities, values, and needs that must be both recognized and negotiated if civic food networks are to reach their full potential. The experience of this farmer collective also highlights how the entrenchment of individualistic subjectivities in the farming community may be particularly salient among direct farm marketers who have built brands and businesses based on an individual farm identity - an important consideration in any strategy aimed at scaling up local food through collective action.

Phil Mount and John Smithers' paper presents a bifurcated typology of "local beef" groups in Ontario. The first, a farmer-owned cooperative type, focused on direct marketing to consumers. The second local beef group was led by intermediaries that sold wholesale but involved little farmer participation in the governance of the group. Mount and Smithers found that farmers were more satisfied with and committed to the farmer-owned direct marketing model, which better reflected the principles of cooperative ownership and control. Farmers involved in the intermediary-led chains felt these groups reproduced the negative experiences of selling to commodity chains and large packers. However, farmers in the cooperative direct marketing model were dissatisfied with low volumes, which threatened the viability of these groups. One possible future direction for the farmer-owned cooperative model is to develop a hybrid marketing approach (as per Anderson et al., this issue) where wholesale relationships are developed to complement the direct marketing channel. These cooperatively owned and controlled groups may also be well positioned to tap into cooperative support networks (Sumner et al., this issue) to explore linkages with cooperative intermediaries who could facilitate volume sales yet would be more attuned to the needs and values of participating farmers.

Thomas Gray's commentary identifies the need for developing multistakeholder cooperatives where, rather than being pitted in competitive market relations, farmers, consumers, and other food-system actors cooperate as co-owners. These multistakeholder organizational structures resonate strongly with the literature on civic food networks 
that has emerged out of Europe ${ }^{2}$ (Renting et al., 2012) that emphasize the importance of civic governance (especially cooperation between farmers and consumers in the development of new modes of food provisioning) and of political action, both of which are based on civic and democratic principles rather than strictly on market considerations. There is a need for further research on the relationship between cooperation and competition between different actors and cooperative types in multistakeholder cooperatives, cooperative support networks and civic food networks. Such analysis would provide a better understanding of both the potential and the limits of cross-stakeholder cooperation, and could identify best practices for creating synergies and navigating tensions.

\section{Jacqueline R. LeBlanc, David Conner,} Glenn McRae, and Heather Darby's study found that nonprofit food hubs in Vermont were vulnerable in part due to their reliance on external (state and/or charitable) funding and their related failure to adopt conventional business principles. This paper raises two important questions. First, what level and type of state support is appropriate to most effectively enable cooperative alternative food networks without creating dependence or vulnerability? More controversially, we might reconsider the tendency of commentators to uncritically lament the dependency of the social economy on the state. These nonprofit and cooperative initiatives may both require and warrant ongoing support because they offer a public good by supporting the development of healthy, environmentally friendly food systems or contributing to social inclusion and cohesion - a much longer-term project of social change that may never be accomplished within the limits of the current market logic. This perspective would require cooperators and researchers to shift focus from intervening in individual initiatives to engaging in analysis and actions to affect the wider political economic context, and thus to complement internal pragmatic strategies (e.g., business

\footnotetext{
${ }^{2}$ See the special issue on civic food networks in the International Journal of Sociology of Agriculture and Food (2012; volume 19, issue 3), at http://ijsaf.org/
}

development) with external political ones (e.g., advocacy).

Second, LeBlanc et al.'s conclusion speaks to the inherent paradox of the social economy that is clearly woven through most of the papers in this issue: to what extent should cooperative alternative food networks adopt the tools and logics of the market economy to achieve their goals and what impact will this have on sustaining their broader social, political and ecological rasions d'etre? Cooperators and cooperative developers must proceed with caution when applying economistic and bureaucratic strategies to these organizations. The incremental application of economic rationality risks undermining the multifunctional potential of these initiatives and can erase possibilities for more radical and oppositional forms of economic organizing and politics. If not approached reflexively, conventional business-planning tactics and strategies may contribute to the conventionalization of these initiatives (Cameron 2010) whereby they come to be virtually indistinguishable from profit-driven firms (see Gray, 2008, and Mooney, 2004, for related discussion in cooperative literature). Similar tendencies have been reported earlier with respect to conventionalization in the organic food market (Guthman, 2004).

In the short term, there is a great need to explore alternative development and planning strategies that increase the resilience of cooperative alternative food networks without compromising the non-economic values and goals embodied within these multifunctional initiatives. For example, Oliver Moore, Olive McCarthy, Noreen Byrne, and Michael Ward present a case study from Ireland that examines the "reflexive resilience" of a community supported agriculture initiative. When faced with economic hardship, rather than adopting conventional business practices, the CSA engaged in a participatory decisionmaking process and addressed its challenges through a commitment by members to provide more in-kind labor to operate and manage the initiative. In contrast to adopting the conventional market-oriented solutions of increasing efficiency, convenience, and competitive pricing, the CSA opted for an alternative development trajectory that emphasized participation, civic responsibility, 
and volunteerism. The CSA profiled in this case study exemplifies reflexive governance processes (Marsden, 2012) that allow participants, at a local level, to intentionally and proactively contend with the paradoxes that arise when blending social, political, and economic enterprise.

Recommendations for struggling initiatives to become "better businesses" perhaps arise from an analytic framework that is too localized and narrow in focus, where more challenging questions related to the political-economic, social, cultural, and regulatory context are left unprobed. In addition to looking inward and critiquing management practice and organizational governance, there is more space for analyses that more thoroughly address how rules, norms, and regulations are preventing cooperative alternative food networks from effectively pursuing a more holistic community development agenda. Confronting these broader structures will require politicized solutions and collective action across multiple scales. The organizational spaces that are constructed within cooperative alternative food networks may provide an opportunity to encourage more politicized actors and actions (e.g., Lamine, Darolt and Brandenburg, 2012).

Marie-Josée Massicotte's paper examines the more political dimensions of cooperative alternative food networks. She examines two cooperatives of the landless rural workers movement, Movimento dos Trabalhadores Sem Terra (MST), in Brazil. The paper demonstrates how the participatory and democratic processes that characterize cooperative alternative food networks can allow citizens to contest and transform unjust norms and influences, thereby creating new spaces for agency and for both individual and collective transformation. Masicotte's paper suggests that the sociopolitical context of nation, place, and region are fundamentally important in understanding the possibilities for cooperation and for developing collective subjectivities. In her study, the harsh conditions of MST encampments necessitated intimate cooperative efforts to provide for their most basic needs. These prefigurative encounters provided a foundation of interdependence that was built upon through the development of cooperative enterprise and was found to be fundamental to their cooperative identity and practice. Although the MST encampment experience arose in a specific national context, there are important lessons to learn for other initiatives in terms of strategies to foster what Massicotte refers to as "sociopolitical imaginaries, values, and norms that can foster and sustain greater cooperation" (p. 18).

Beyond economic and social innovation, Masicotte illustrates how cooperatives can be pivotal in consolidating and strengthening social movements. In her study, the MST cooperatives were embedded in a "permanent struggle that ultimately aims at dislodging capitalist markets to redistribute wealth more equitably in society" ( $\mathrm{p}$. 11). The politicized nature of the MST cooperatives is notably juxtaposed with the less politicized cooperative alternative food networks from the global north profiled in this issue. The efforts of many northern cooperatives focus on communitybuilding work that coexists quietly in parallel to or as a part of, rather than in opposition to, the dominant system. In this context, the broader structures that undermine the broader viability of these initiatives are often uncontested as co-op participants find ways to work around, rather than to confront, the dominant norms, regulations, and rules that constrain their development and any broader visions of social change.

Failing to collectively confront the regime-level rules and norms that contain these economic experiments in the margins as "niches" (Smith, 2007) limits their potential to replicate, grow, and contribute to broader food system or regime change. However, the seventh cooperative principle of "cooperation among cooperatives" (International Cooperative Association [ICA], n.d.) represents a powerful normative framework for developing and strengthening extra-local ties between cooperative alternative food initiatives and a potential mode of practical and political cooperation across scales. How and to what extent the political potential of these cooperatives and their intercooperative networks are being realized is an open question. Further research could explore the relationship between these economic experiments and more radical oppositional urban and agrarian organizations and movements (e.g., food justice, food sovereignty).

Shirley Thompson, Mohammad Rony, 
Jennifer Temmer, and Darcy Wood's paper locates cooperatives within an indigenous worldview to explore their relationship to food sovereignty and sustainable livelihoods in First Nation communities. Their research approach was rooted in a process of collaborative community development, reflecting a simultaneous effort to understand cooperative alternative food networks while contributing to their development through participatory community development research processes. Through the application of a sustainable livelihoods approach, the co-researchers worked together to build multiple forms of capital (e.g., human, social) through the research process itself. This participatory approach to research was also exemplified in two of the other papers in this issue (Anderson et al., and Moore et al.); collectively these are a testament to the potential of collaborative research for furthering community development and social change.

The papers included in this special were all either single or multiple case studies. There are far fewer systematic, broad-scale and interregional investigations of cooperative alternative food networks that would provide insight into the prevalence, impact, and potential of cooperative alternative food networks. A European Union-funded research project, COFAMI (Encouraging Collective Farmers Marketing Initiatives), chronicled a new wave of European cooperatives that emerged in response to growing societal demands for organic, fair trade, and territorial-based foods (Knickel, Zerger, Jahn, \& Renting, 2008). This network produced both in-depth case study research and also cross-national synthesis that mapped out the landscape of such new forms of collective action as well as the barriers and opportunities for innovation and growth. An important shared characteristic of these new cooperative initiatives is that they go beyond the conventional logic of large-scale marketing cooperatives by extending relevant networks from the traditional farming community to actively include consumers, downstream supply chain actors, public administrations, and/or other rural actors in territorial or community-based networks (Schermer, Renting, \& Oostindie, 2010). Another Canadian research network, Nourishing Communities, provides a promising example of a coordinated, provinciallevel approach to evaluating food hubs and alternative food networks (Blay-Palmer et al., 2013). Finally, cross-national comparative research would generate important insight into the social, cultural, and political-economic context that supports and also limits the development of cooperative alternative food networks.

As these innovative models of cooperative and civic food provisioning emerge, replicate, and transform the foodscape, there is a need for a more systematic and cooperative research agenda. This approach should consolidate and support development strategies and tactics that strengthen democratic ideals, progressive social-environmental values, and enterprise resilience. Such research would be interdisciplinary in nature and create opportunities to further understand and contend with the tensions created when pursuing cooperativism in a hypercompetitive, neoliberal politicaleconomic context. Indeed, the papers represented in this issue shed light on the multiple tensions that define cooperative alternative food networks, including individualism/collectivism, centralization/decentralization, reconnection/disconnection, social/economic purpose, and also those related to gender and class. In order to productively contend with these tensions, the next wave of research on cooperative alternative food networks will be most effective if it is developed cooperatively with the multiple stakeholders involved. Fundamentally, this will involve research processes and extension practices that reflect the democratic values of the movement itself.

\section{References}

Anderson, C. R., \& McLachlan, S. M. (2012). Exiting, enduring and innovating: Farm household adaptation to global zoonotic disease. Global Environmental Change, 22(1), 82-93. http://dx.doi.org/10.1016/i.gloenvcha.2011.11.008

Blay-Palmer, A. D., Knezevic, I., Andrée, P., Ballamingie, P., Landman, K. E., Mount, P. A., . . . Skinner, K. (2013). Future food system research priorities: A sustainable food systems perspective from Ontario, Canada. Journal of Agriculture, Food Systems, and Community Development, 3(4), 227-234. http://dx.doi.org/10.5304/jafscd.2013.034.029 
Cameron, J. (2010). Business as usual or economic innovation?: Work, markets and growth in community and social enterprises. Third Sector Review, 16(2), 93-108. http://www.anztsr.org.au/thirdsector-review.html

Cleveland, D. A., Müller, N. M., Tranovich, A. C., Mazaroli, D. N., \& Hinson, K. (2014). Local food hubs for alternative food systems: A case study from Santa Barbara County, California. Journal of Rural Studies, 35, 26-36. http://dx.doi.org/10.1016/j.jrurstud.2014.03.008

Goodman, D., Goodman, E. M., \& DuPuis, M. K. (2011). Alternative food networks: Knowledge, place and politics. New York: Routledge.

Gray, T. W. (2008). The agriculture of the middle initiative: Premobilizing considerations and formal co-operative structure. Saskatoon, Saskatchewan: Centre for the Study of Cooperatives, University of Saskatchewan.

Guthman, J. (2004). The trouble with 'organic lite' in California: A rejoinder to the 'conventionalisation' debate. Sociologia Ruralis, 44(3), 301-316. http://dx.doi.org/10.1111/j.14679523.2004.00277.x

Ikerd, J. (2012). Cooperation: The key to sustainable livelihoods in food systems. Journal of Agriculture, Food Systems, and Community Development, 3(1), 9-11. http://dx.doi.org/10.5304/jafscd.2012.031.005

International Cooperative Association [ICA]. (n.d.). Cooperative identity, values \& principles. Retrieved May 28, 2014, from http://ica.coop/en/whats-coop/co-operative-identity-values-principles

Knickel, K., Zerger, C., Jahn, G., \& Renting, H. (2008). Limiting and enabling factors of collective farmers' marketing initiatives: Results of a comparative analysis of the situation and trends in 10 European countries. Journal of Hunger \& Environmental Nutrition, 3(2-3), 247-269. http://dx.doi.org/10.1080/19320240802244041
Lamine, C., Darolt, M., \& Brandenburg, A. (2012). The civic and social dimensions of food production and distribution in alternative food networks in France and Southern Brazil. International Journal of Sociology of Agriculture and Food, 19(3), 383-401. http://ijsaf.org/

Levkoe, C. Z. (2011). Towards a transformative food politics. Local Environment, 16(7), 687-705. http://dx.doi.org/10.1080/13549839.2011.592182

Levkoe, C. Z., \& Wakefield, S. (2014). Understanding contemporary networks of environmental and social change: Complex assemblages within Canada's 'food movement.' Environmental Politics, 23(2), 302-320. http://dx.doi.org/10.1080/09644016.2013.818302

Marsden, T. (2012). Third natures? Reconstituting space through place-making strategies for sustainability. International Journal of Sociology of Agriculture and Food, 19(2), 257-274. http://ijsaf.org/

Mooney, P. H. (2004). Democratizing rural economy: Institutional friction, sustainable struggle and the cooperative movement. Rural Sociology, 69(1), 76-98. http://onlinelibrary.wiley.com/doi/10.1526/00360 1104322919919/abstract

Renting, H., Schermer, M., \& Rossi, A. (2012). Building food democracy: Exploring civic food networks and newly emerging forms of food citizenship. International Journal of Sociology of Agriculture and Food, 19(3), 289-307. http://ijsaf.org/

Schermer, M., Renting, H., \& Oostindie, H. (2010). Collective farmers' marketing initiatives in Europe: Diversity, contextuality and dynamics. International Journal of Sociology of Agriculture and Food, 18(1), 1-11. http://ijsaf.org/

Smith, A. (2007). Translating sustainabilities between green niches and socio-technical regimes. Technology Analysis and Strategic Management, 19(4), 427-450. http://dx.doi.org/10.1080/09537320701403334 